\title{
Outbreaks Surveillance of Unknown Origin Acute Fever in Jeneponto, South Sulawesi
}

\author{
Dwi Priyanto $^{1 *}$, Corry L.J. Sianturi ${ }^{1}$, Jastal $^{1}$ \\ ${ }^{1}$ Banjarnegara Health Research and Development Unit, 16A Selamanik Street, 53415, Central of Java, Indonesia \\ *Corresponding Author. Email: dwipriyanto76@gmail.com
}

\begin{abstract}
April 2019, the Jeneponto District Health Office be up against outbreak of the acute fever of unknown origin in Garonggong, Tuju Village, West Bangkala District, there were 70 patients with three deaths. South Sulawesi Provincial Health Service investigation found that 27 patients had fever accompanied by nausea, vomiting and headaches since the end of March 2019. Patients also felt pain in the muscles and joints so that there was a suspicion of Leptospira and or Rickettsia infection in the area. Banjarnegara Health Research and Development Unit conducted an epidemiological investigation by examining blood and kidney samples in reservoir animals in the area. Rat capturing was carried out for 2 nights to test Leptospira and Rickettsia content with PCR Methods. A total of 20 rats were caught and PCR test found one individual rat of Rattus tanezumi species positively infected by the bacteria Leptospira sp. Rickettsia examination shows that Xenopxylla cheopis fleas infested R. tanezumi positively infected with Ricketsia sp. We conclude that Garonggong, Tuju Village, West Bangkala Subdistrict, Jeneponto Regency, South Sulawesi has the potential for rat-borne disease transmission, particularly Leptospirosis and Rickettsiosis.
\end{abstract}

Keywords: epidemiological investigation, Leptospirosis, Rickettsia

\section{INTRODUCTION}

An unknown pathogens cause of fever suddenly occured in Garonggong Hamlet, Tuju Village, Bangkala Barat District, Jeneponto Regency, South Sulawesi in April 2019, caused 70 illnesses and three deaths. The local government-South Sulawesi Provincial Health Office and Jeneponto District Health Services teams perform rapid respond to investigate into this case and confirm the state of affairs. it was reported that 27 people from this location being suffered from fever accompanied by nausea, vomiting and headaches since 27 March 2019. Of the total cases of the disease, 2 people died. In addition to nausea and vomiting, pain symptoms in the muscles and joints were arisen.

The team arranged blood samples survey for the pathogen examination. As a result, the test showed 2 positive of 25 samples tested with Tipoid RDT; 20 negative samples of the DDR test; and 60 samples whose results were all negative of the malaria RDT test. To ensure the potential transmission of diseases from animals in Garonggong, samples from the community were sent to check for Dengue, Chikungunya, and Zika diseases at BBTKLP Class 1 Makassar, but the results of all the three diseases were negative also.

The South Sulawesi Provincial Health Office continued the inquitition of the outbreak, invites any other institution to assist the efforts. Referring to the information of symptoms of the diseases, epidemiological investigations establish various types of diseases with similar symptoms as a target. Nipah Virus, Hendravirus, Hantavirus, Leptospira, Rickettsia, chemical poisoning and Antrax ${ }^{5,6}$ was hipothesised as potential sources of the responsible agent contribute to the outbreaks. Banjarnegara Health Research and Development Unit have been participated by conduct an epidemiological investigations focusing on the possibility of animals borne diseases, especially leptospirosis and rickettsiosis transmitted by rat.

\section{METHOD}

To identify outbreaks of unknown origin acute fever, we collect rats-leptospirosis reservoar- blood and kidney speciment and flea speciment. Rat captured on Garonggong, West Bangkala, Jeneponto, South Sulawesi at May 12th-17th 2019.

The activity of rats capturing began by setting 190 live traps in the afternoon. every houses in the village installeds 2 traps respectively, placed where they are thought to be frequented by rats. We used roasted coconut as a lure and the arrest was held for 2 consecutive nights. Traps that already contained rats were labeled and put into cloth bags. Furthermore, rats were stunned by anesthetized Ketamine HCL $100 \mathrm{mg} / \mathrm{kg}$ body weight of rats, then were taken blood and fleas and then dissected to take the kidneys as an examination of the presence of pathogens. The kidneys are examined to find Leptospira bacteria by PCR method. Ectoparasites were identified and examined for Ricketsia spp by PCR method. The examination was 
carried out at the Microbiology, Biomolecular and Immunology Laboratory of the Banjarnegara Research and Development Center.

\section{RESULTS AND DISCUSSION}

Garonggong is a hamlet in Tuju Village, West Bangkala District, South Sulawesi province. Traps were installed throughout all houses and disperse on the residential area.

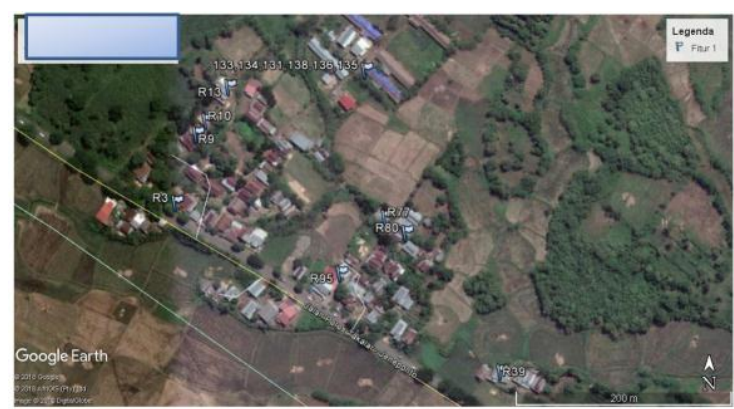

Figure 1. Map of Garonggong and rat captured point.

Recapitulation of rat capture dan results of Leptospira examination showed in Table 1 and Figure 2.

Table 1. Recapitulation of rat capture in Garonggong Hamlet dan the results of Leptospira examination using PCR method
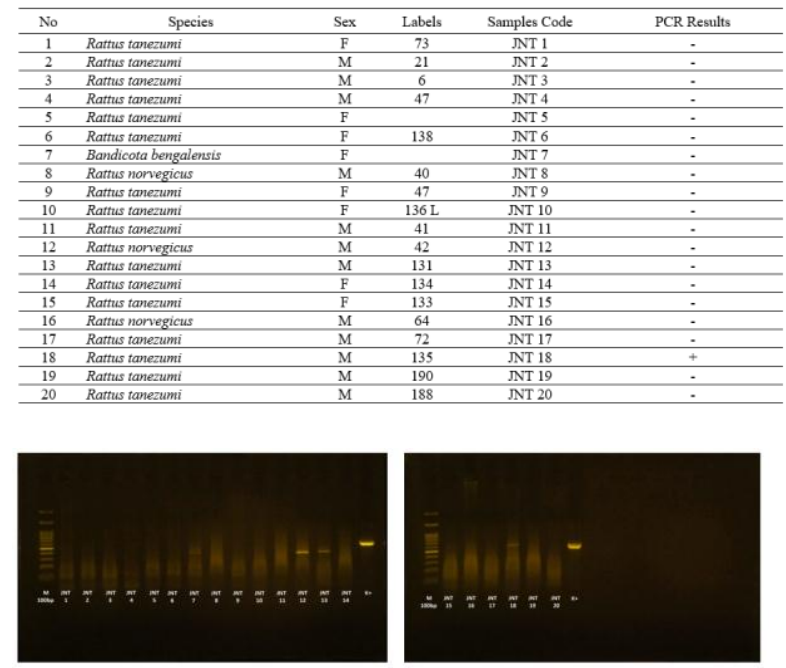

Exp.: M : Marker; JNT 1- 20 : Samples; K+ : Positive Control

Figure 2. Results of Leptospira examination in rat kidney samples using PCR method

The results of examination of the presence Rickettsia spp. using PCR method showed in Table 2 and Figure 3.
Table 2. Results of examination of the presence Rickettsia spp. in rat ectoparacites captured in Garonggong Hamlet using PCR method

\begin{tabular}{clcc}
\hline No & \multicolumn{1}{c}{ Type of Ectoparacites } & Samples Code & PCR Results \\
\hline 1 & Fleas $(X$. cheopis $)$ & JNT 2 & + \\
\hline 2 & Fleas $(X$. cheopis $)$ & NNT 3 & - \\
\hline 3 & Mites & JNT 3 & - \\
\hline 4 & Mites & JNT 4 & - \\
\hline 5 & Fleas $(X$. cheopis $)$ & NNT 5 & - \\
\hline 6 & Fleas $(X$. cheopis $)$ & JNT 10 & - \\
\hline 7 & Fleas $(X$. cheopis $)$ & JNT 14 & - \\
\hline 8 & Mites & JNT 14 & - \\
\hline 9 & Fleas $(X$. cheopis $)$ & JNT 15 & - \\
\hline 10 & Mites & JNT 15 & - \\
\hline 11 & Ectoparacites & JNT 16 & - \\
\hline 12 & Fleas $(X$. cheopis $)$ & JNT 17 & - \\
\hline 13 & Mites & JNT 17 & - \\
\hline 14 & Fleas $(X$. cheopis $)$ & JNT 18 & - \\
\hline
\end{tabular}
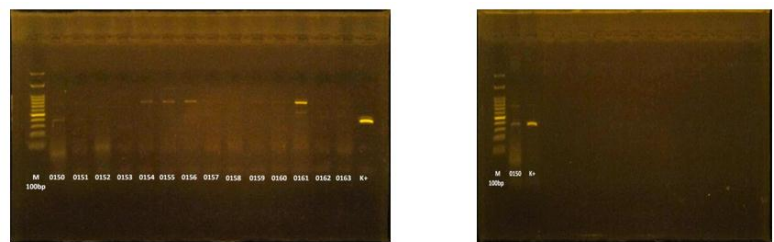

Exp.: M: Marker; K+: Positive Control; 0150-0163:

Samples Code

Figure 3. Results of examination of the presence Rickettsia spp. using PCR method

\section{DISCUSSION}

Inhabitant settlements in this region are grouped and separated from others by paddy fields and dry fields boundaries (Figure 1). The fever outbreak that harm people only in this region indicates the cause of the disease comes from the internal region. it strongly indicates environmental factors comprise the main cause of the disease. Based on this fact, we have direct the investigation targeting pathogen contained in the area. Our team conducted an epidemiological investigation based on this assumption. As part of a main team that conducts a comprehensive investigation, we only focus on suspicion of animal-borne disease transmission. Especially, the notions that the symptoms of the disease are similar to those of leptospirosis and rickettsiosis, so we collect samples from reservoir of the both: rats.

The number of rat obtained from two nights of trapping was 20 individu, Rattus tanezumi or house rat was the major species. Generally, they were trapped in different houses, indicates an even distribution pattern of rat in resident houses. However, there were broillers hennery in the northern side of the settlement, we caught a total of 6 individual rat in and around (Figure 1; Table 1, Label 131138), illustrates that the rat density in the coop has been dense and tends to cluster. Rat existance in this location has been supported by abundant food sources in the cage, rats utilize chicken food scraps as a nourishment. Furthermore, spacious construction allow rats live in much numbers concomitant the large carrying capacity of the environment. Another predispose factor was the minimum level of control of rats, the chicken farmer employee 
leads to those disease. There needs to provide a comprehensive reports (joint reports) regarding epidemiological investigations which have been done jointly together with several instations during extraordinary outbreaks events in Garonggong Hamlet.

\section{ACKNOWLEDGMENT}

This work has been financed by Banjarnegara health research and development unit. We would like to thank the local government-South Sulawesi Provincial Health Office and Jeneponto District Health Services for their cooperation support; and to Salatiga Center for Disease Vector and Reservoir Research and Development Team for their collaboration on Jeneponto Outbreaks Surveillance.

\section{REFERENCES}

[1] Wabah Penyakit Misterius di Jeneponto Ratusan Orang di rukiyah.

[2] Dinkes Sulsel Identifikasi Penyakit Misterius di Jeneponto Mirip Tifus.

[3] Hadapi Penyakit Misterius Warga Jeneponto Diminta tak Panik.

[4] BBTKLP Kelas I Makassar. Laporan Perkembangan Peningkatan Kasus Suspek Chikungunya Di Kabupaten Jeneponto 2019.

[5] Levett PN, Branch SL, Edwards CN, Hospital QE. Detection Of Dengue Infection In Patients Investigated For Leptospirosis In Barbados. 2000;62(1):112-114.

[6] Mwachui MA, Crump L, Hartskeerl R, Zinsstag J. Environmental and Behavioural Determinants of Leptospirosis Transmission: A Systematic Review. 2015:1-15. doi:10.1371/journal.pntd.0003843.

[7] Balai Litbang B2P2VRP Salatiga. Laporan Akhir Riset Khusus Vektor dan Reservoir Penyakit Provinsi Sulawesi Selatan. 2017.

[8] Widiastuti D, Trisnawati UF, Pramestuti N. Deteksi Rickettsia spp. pada Pinjal Tikus di Kota Semarang. 2018;1(16).

There needs to increase the vigilance of the potential transmission of infectious desease by vector and reservoir in Garonggong Hamlet. Counseling and training about transmission of infectious desease by vector and reservoir need to be provided for health workers to find out the appropriate prevention, control and management. It is necessary to provide device for leptospirosis and rickettsiosis detection in public health service as first detection tool if there are diseases with symptoms that 